\title{
ČESKÁ BEETHOVENIANA RUDOLFA PEČMANA
}

Osobnost a dílo Ludwiga van Beethovena tvoří jednu ze základních os v bohatém muzikologickém odkazu Rudolfa Pečmana (1931-2008). V této tematice navazuje na linii svých předchůdců a pedagogů Masarykovy university, jejíž východisko tvoř́i výzkumy a úvahy Vladimíra Helferta. Na rozdíl od svých brněnských učitelů Jana Racka a Bohumíra Štědroně zbavuje Pečman Beethovena nánosů dobové rétoriky padesátých let. Beethoven v jeho pojetí přestává být hrdinou, bojovníkem, revolucionářem, př́padně nezní v chorálu dělnictva, ${ }^{1}$ nýbrž stává se opět skladatelem a myslitelem. Pečman se soustředí především na hudbu a na slohová, estetická, případně filosofická východiska. Pouze v padesátých a šedesátých letech se v Pečmanově beethovenovském slovníku ojediněle objeví slovo ,pokrokovost“, a to v souvislosti s repertoárem bonnského divadla za doby Beethovenova mládí: ,Ale již předtím, než se vedeni divadla ujala tato společnost, mělo bonnské divadlo pokrokový charakter. [...] V pokrokově zaměřeném repertoáru se začaly uplatňovat národni tendence po vzoru vídeňském a mannheimském. "2 Poněkud nesourodě působí zmínka o ,pokrokovém přístupu“ k citacím ruských lidových písní v Práčově sborníku: ${ }^{3}$ o něco dříve byl totiž Práč podroben kritice za nepřesnosti zápisu. ${ }^{4}$

Pečmanovy beethovenovské studie jsou také názorným př́kladem jeho literárního stylu. Autor v nich - podobně jako ve většině své tvorby - nerozlišuje mezi určením vědecké obci a širšímu hudby milovnému okruhu čtenářò. Stejnou

1 Srov. např. RACEK, Jan. Beethoven: růst hrdiny bojovnika. Praha: SNKLHU, 1. vyd. 1955, 2. vyd. 1956; ŠTĚDROŇ, Bohumír. Ludwig van Beethoven: člověk, umělec, revolucionáŕ. Estetická výchova, 1965-66, roč. 4, č. 9, s. 370 - 373, č. 10, s. 422 - 424; TÝŽ. Beethoven lidový: chorál dělnictva podle Beethovenovy sonáty. Časopis národního muzea. Oddil věd společenských, 1963, roč. 132, s. 100-107.

2 PEČMAN, Rudolf. Jiří Antonín Benda a Ludwig van Beethoven: pokus o srovnání jejich vzájemného slohového vztahu. Československá beethoveniána, 1965, roč. 2, č. 3, s. 144. Beethovena: př́spěvek k otázce citací ruských lidových písní. In Sborník prací filosofické fakulty brněnské university: řada uměnovédná, 1957, č. 1, s. 59. 
studii, kterou uveřejnil v odborném muzikologickém sborníku, neváhá publikovat např. v knížce pro cyklus koncertů brněnského Kruhu přátel hudby. Uvedené tendenci odpovídá i způsob vyjadřování, založený na jasnosti a srozumitelnosti. Žádný „,metajazyk“, nýbrž ušlechtilý a bohatý komunikační nástroj, který v sobě nese vlivy klasiků české, ale i německé literatury. Časté literární, estetické, uměnovědné, př́ípadně filosofické odkazy jsou projevem všeobecného vzdělání a kulturního rozhledu svého autora, který nikdy nepodlehl nešvaru úzké zahleděnosti na jedno téma, které je zkoumáno vytrženě z širšího kontextu historického, literárního a uměleckého.

Pečmanovi ovšem zůstaly cizí některé hudební a myšlenkové postupy tzv. postmoderní epochy. Proto překvapí, že se u Beethovena věnuje též jeho „minimalistickým skladbám“, jak o tom svědčí titul: „,Minimalistische“ Kompositionen Ludwig van Beethovens. ${ }^{5}$ Pokud ovšem blíže nahlédneme do sborníku z bratislavského symposia, na němž byl tento referát $\mathrm{v}$ roce 2005 přednesen, zjistíme, že Beethoven se kupodivu stal - vedle Perotina, Schuberta, Chopina, Liszta, Sibelia - jedním z předchůdců minimalismu, konkrétně především Steva Reicha.

Nejvýznamnějším tématem Pečmanova beethovenovského bádání je skladatelovo jevištní dílo. Tato tematika, rozvíjená přes dílčí studie a publikace jako Beethoven dramatik (1978) či Beethovens Opernpläne (1981), vrcholí v syntetické monografii Jevištní dílo Ludwiga van Beethovena (1999). Pečman se naopak nezabývá Beethovenovými pobyty $\mathrm{v}$ Praze, západočeských lázních nebo na zámku Hradec u Opavy, nevěnuje se ani průzkumu dokumentů v českých a moravských archivech. Nereflektuje tedy tematiku, která je hojně zastoupena v českých i zahraničních muzikologických studí́ch. ${ }^{6}$

Beethovenovská bohemica zaměřuje zejména na Mistrův tvůrčí vztah k českým skladatelům a interpretům období klasicismu. Největší význam tu má Jiří Antonín Benda, dále jsou reflektováni Jan Václav Stich-Punto, Václav Krumpholz a Antonín Práč. Z období hudby 19. století je kladen důraz na Bedřicha Smetanu. Pečman se naopak - na rozdíl např. od Bohumíra Štědroně - nezabývá postojem Leoše Janáčka k vídeňskému skladateli. ${ }^{7}$ Výjimkou je uveřejnění Janáčkova fejetonu Chci mračna bezprostředně chytit, který vyšel roku 1927 v Lidových novinách. ${ }^{8}$ Historicky tedy své výzkumy začíná J. A. Bendou a končí Smetanou.

5 In Od Perotina po Steva Reicha: idey ,minimálneho “ $v$ hudobných dejinách a v súčasnosti. Bratislava: Hudobné centrum, 2005, s. 130-146.

6 Např. RACEK Jan. Beethoven a české země. Brno: Universita J. E. Purkyně, 1964; PLEVKA, Bohumil. Beethoven a Praha. Praha: Supraphon, 1975; TÝŽ. Beethoven v českých láznich. Liberec: Severočeské nakladatelství, 1975; Ludwig van Beethoven im Herzen Europas. Leben und Nachleben in den Böhmischen Ländern. Oldřich Pulkert - Hans Werner Küthen - Karel Boženek (eds.). Prag: Resonus, 2000, atd.

7 ŠTĚDROŇ, Bohumír. Leoš Janáček und Ludwig van Beethoven. In Bericht über den internationalen Beethoven-Kongreß. Berlin: Verlag Neue Musik, 1971, s. 125-130. 
Důležitým pramenným materiálem jsou Pečmanovi studie Vladimíra Helferta o české hudbě 18. století, z nich zejména Průkopnický význam české hudby 18. století (1939). Některé názory, jež Helfert pouze načrtl, posléze rozvádí a domýšlí.

\section{Slovanské zdroje}

Širším východiskem beethovenovského proudu v Pečmanově muzikologickém díle jsou slovanské reálie. Těmi se zabýval již ve své diplomové práci Slovanské prvky $v$ díle Ludwiga van Beethovena $\mathrm{z}$ roku $1954 .{ }^{9}$ Ve druhé polovině padesátých let vytváří dvě základní studie, v nichž sleduje možné slovanské vlivy na Beethovenovu tvorbu. Ve Dvou jihoslovanských pisních v Beethovenově „Pastorálni "10 se zabývá možnými citacemi písní jižních Slovanů v Symfonii c. 6 F dur, op. 68. Za citaci označuje hlavní téma první věty, kde Beethoven užil píseň Širvonja do širvonja. Tuto melodii zaznamenal Franjo Ksaver Kuhač ve sbírce Južnoslovjenske narodne popijevke (Chansons nationales des Slaves du Sud, Zagreb 1880). Jedná se o starou srbskou obřadní píseň, která pravděpodobně pochází z pohanské doby a zpívala se v období slunovratu.

Vzhledem k tomu, že se jedná téměr̆ o přesnou citaci, klade si Pečman otáz$\mathrm{ku}$, jakým způsobem mohl přijít Beethoven s jihoslovanskými písněmi do styku. Podnětem byl nejspís autentický sluchový vjem - Kuhačova sbírka vyšla více než padesát let po Beethovenově smrti. Vysvětlení podává prostředí, v němž se Beethoven pohyboval. Krajina v okolí Vídně, tzv. vídeňská kotlina (Wiener Becken) představovala národnostně a národopisně smíšenou oblast, kde se jihoslovanská lidová kultura vzájemně prolínala s kulturou dolnorakouskou. Písně jižních Slovanů sem migračně pronikly ze svého původního teritoria a smísily se s domácím folklorem. Svědčí o tom jejich národnostní nevyhraněnost, takže Beethoven si prri poslechu nemusel uvědomovat jejich slovanský původ. Navíc je mohl slyšet s novým, zřejmě německým textem. Patrně proto označuje Pečman za nesmysl názor Julia J. Majora, ${ }^{11}$ že melodie ,Pastorálni “ se rozšśríily po jihoslovanských zemích a měly př́mý vliv na jejich lidovou tvorbu. Přesto nás napadá otázka, zda Beethoven nemohl ovlivnit Kuhačův zápis (sbírka vyšla 1880) shodnou volbou tóniny $\mathrm{F}$ dur.

Ještě volnější vztah k Beethovenově symfonii představuje druhá píseň Kad sam $v$ Šopron školu hodil, původem z Velikého Borištofu v Šoproňské župě. Jedná se totiž pouze o epizodní téma finální věty, které nemusí být citací, ale mohlo vyplynout z práce s tématem hlavním.

Pečman popisuje též oblasti, kde přišel Beethoven do styku s prvky jihoslovanského folkloru. Mezi nimi uvádí esterházyovské sídlo v Eisenstadtu, které

a oddechu, 1977, s. 35.

9 Filosofická fakulta Masarykovy university, 1954, rkp.

10 Hudební rozhledy, 1957, roč. 10, č. 11, s. 455-457.

11 Die Volksmusik der Südslaven, 1912. 
navštěvoval díky intenzivním stykům s hrabětem Mikulášem Esterházym. Jednalo se rovněž o národnostně smíšenou oblast, kterou osídlili Charváti, jak o tom svědčí slovanské pojmenování místa: Železnovo.

V každém př́ípadě obě zmíněná témata jsou národnostně nevyhraněná a svojí strukturou odpovídají typu klasicistní melodiky. Tak je patrně vnímal též Beethoven, a to bez jejich původních slovanských vazeb.

Opačný případ představují Smyčcové kvartety op. 59, „Razumovské“ (1806), jimiž se Pečman zabývá ve studii Práčův písňový sborník z r. 1790 a „Razumovské kvartety " L. van Beethovena ze stejného období. ${ }^{12} \mathrm{~V}$ nich jsou ruské prvky podníceny již objednávkou, nebot' kvartety vznikají z popudu knížete Razumovského, ruského vyslance ve Vídni, jemuž jsou také věnovány.

Beethoven tu cituje dvě ruské písně, s nimiž - na rozdíl od zmíněných jihoslovanských - nemohl prijít do př́mého styku. Zdrojem je mu sbírka ruských lidových písní, kterou vytvořil český emigrant Jan Ivan Bohumír Práč (Petrohrad 1790, 2. vyd. 1806). Podle Pečmana nebyla otázka těchto citací dosud (tj. 1957) podrobně řešena. Nabízejí se tak otázky hudebně estetické, folkloristické a analytické (hudebně tektonický rozbor). Pokud byl Beethovenovi východiskem Práčův zápis, je nutno nejprve charakterizovat jeho podstatu.

Práč zapisoval na sklonku 18. století písně v duchu nového „romantického“ pojetí folkloru, jak jej formuloval německý filosof Johann Gottfried Herder. Zápisy vznikaly ve stylu tehdejší klasicistní manýry, tzn. byly přizpůsobovány klasické formě, harmonii, rytmice apod. Práč dělil původní ruské melodie do taktů o menším počtu dob, čímž ztratily svou typickou dlouhodechost. Užíval - často nesprávně - nejjednodušší harmonické funkce (tónika, dominanta). K písním přistupoval z ryze hudebního hlediska, tzn. nebral ohled na vztah nápěvu a textu. Beethoven, který neměl žádné znalosti z oblasti ruského folkloru, tak přejímal pouze melodie deformované Práčovým zápisem. Ty se mu jevily jako typicky „ruská" témata. Přesto jsou tato témata národnostně vyhraněnější než dvě jihoslovanské písně.

Otázka ruského původu zmíněných témat $\mathrm{v}$ „Razumovských kvartetech “vedla někdy až k naprosté negaci jejich ruského zdroje. Např. Theodor Helm ${ }^{13}$ tvrdí, že oba kvartety, kde se objevují ruské písně, nemají národní zabarvení; jsou „praněmecké“, „universálně kosmopolitické“. Pečman jeho stanovisko odmítá a označuje je za šovinistické.

Přestože ruské folklorní prvky neměly žádný zásadní vliv na Beethovenovu tvorbu, Pečman uvádí, že ve zmíněných kvartetech je jejich význam větší, než by se zdálo na první pohled. Ruské písně prý působily i při volbě dalšího tematického materiálu. Jejich charakter pak zásadně ovlivnil způsob kompoziční práce, především v užití kontrapunktu.

12 In Sborník praci filosofické fakulty brněnské university. Řada uměnovědná, 1957, č. 1, s. 53-63.

13 Beethovens Streichquartette. Lipsko 1910. 
Jedná se především o píseň Ach, talan 'li moj (Kvartet č. $1 F$ dur, 4. věta), která skladatele inspirovala $\mathrm{k}$ důmyslné kontrapunktické práci, zejména od taktu 100. Podle Pečmana je to dáno skrytou pofyfonií v melodice písně - tematický materiál tak nepř́ímo určil způsob zpracování. Zajímavý je rovněž Beethovenův př́stup $\mathrm{k}$ dalším charakteristickým rysům předlohy. Píseň sice přesně cituje, ale v subdominantní tónině. Primární zdroj dramatizuje, a to prostřednictvím tempa. Táhlou píseň zadumaného charakteru (u Práče Molto Andante) pojímá v rychlém tempu (Allegro, Presto), s výraznými gradačními prostředky v oblasti dynamiky, agogiky, diminuce, augmentace atd. Na původní charakter písně však nerezignuje. Její dumný, lyrický tón nechá zaznít před závěrečným Prestem, tedy na dramaticky nejvypjatějším místě (Adagio, ma non troppo, piano), které tvoří jakousi peripetii před závěrečnou Codou.

Vzhledem k tomu, že melodika druhé písně Už kak slava, tebe, Bože, na nebesi (Kvartet č. 2 e moll, střední část 3. věty [Maggiore]) odkazuje spíše k homofonnímu zpracování, Beethoven nepojímá tuto pasáž důsledně kontrapunkticky, s výjimkou umělé kánonické imitace $\mathrm{v}$ oktávě před závěrem. Ačkoli opět posouvá jinak přesnou melodickou citaci do dominantná tóniny, vystihuje slavnostní charakter písně $\mathrm{s}$ důrazem na jasnost a lineární přehlednost. Původní materiál však opět dramatizuje zrychlením tempa, tentokrát méně výrazným než u předchozího príípadu - z původního Andante (Práč) na Allegretto.

Širší slovanská tematika proniká od sedmdesátých let též do hlavního Pečmanova zájmu o Beethovena, kterým je jeho jevištní dílo. Pečman se věnuje slovanským námětům, které hodlal Beethoven zhudebnit, jako jsou Libussa, Wanda, Wladimir der Große, Drahomira, zejména ve studii Slawische Sujets in den Opernplänen L. van Beethovens. ${ }^{14}$ Tyto poznatky jsou vřazeny též do syntetické monografie Jevištní dílo Ludwiga van Beethovena (1999).

\section{Bendův dramatický sloh}

V šedesátých letech otevírá Pečman otázku vzájemného slohového vztahu Ludwiga van Beethovena a Jiř́ho Antonína Bendy. ${ }^{15}$ Nejprve se zabývá Beethovenovým raným obdobím v Bonnu, kde se tamější rodák seznámil s Bendovými skladbami jednak prostřednictvím svého učitele Christiana Gottloba Neefa,

14 In Hudba slovanských národi̊ a její vliv na evropskou hudební kulturu. Brno: Česká hudební společnost, 1981, s. 353-363.

15 K otázce slohového vztahu Jiř́ho Bendy a Ludwiga van Beethovena. Musejní zprávy Pražského kraje, 1959, roč. 4, č. 1-2, s. 24-34; Ästetisch-theoretische Ausgangspunkte und stilistische Verwandtschaft im Schaffen von Jiří Benda und Ludwig van Beethoven: Versuch um eine Komparation. In Sborník prací Filozofické fakulty Brněnské univerzity, H 2, 1967, s. 43-52; Ludwig van Beethoven und Jiří Antonín Benda. In Bericht über den Internationalen Beethoven-Kongreß. Berlin: Verlag Neue Musik, 1971, s. 453-464. 
jednak díky místnímu Národnímu divadlu, jehož představení navštěvoval a stal se členem jeho orchestru.

Problém vztahu Benda - Beethoven zkoumá Pečman z hlediska filosofického a estetického kánonu obou mistrů, z hlediska jejich tvůrčí estetiky. V komparaci Benda - Beethoven vidí zdroj osvětlení jednoho z kořenů Beethovenova stylu, kterým je vnitřní dramatismus a appassionatový sloh středního, tzv. heroického období. Oba skladatelé vycházeli z týchž zásad afektové teorie. Odmítali estetický naturalismus, jak jej formuloval Charles Batteux v úvahách o napodobení prírodních jevů a afektů $v$ hudbě. Naopak vždy zdůrazňovali nutnost stylizačního procesu respektováním zákonů hudební stavby a motivické práce. Ve svých dílech preferovali patetičnost a vzrušenou citovost. $K$ těmto závěrům přispěl významně též charakter filosofického vzdělání, jímž oba tvưrci prošli.

Filosofickou oblastí, kde se Beethoven stýkal s Bendou nejpodstatněji, bylo učení Jeana-Jacquesa Rousseaua o teorii řeči a požadavku pravdivosti v hudbě. U Rousseaua vedly tyto úvahy (např. o problému deklamace) $\mathrm{k}$ vytvoření melodramu, jehož principy dovedl k dokonalosti Benda ve svém gotském období. Zatímco však Benda znal Rousseauovy spisy př́mo, Beethovena s nimi seznámil jeho učitel na bonnské universitě Eulogius Schneider. Byl to právě Schneider, který nesouhlasil $\mathrm{s}$ Bateuxovým př́sným napodobovacím principem a v duchu Winckelmannově stavěl uměleckou krásu výše než pravdu. Podobné názory zastával též Mosse Mendelssohn, jehož spisy Beethoven studoval. Mendelssohn prohloubil myšlenku stylizačního procesu v umění a hudbě a tvrdil, že hudba není mechanickým napodobením prrírodních jevů: jedná se o povýšené napodobení estetické.

V otázce vlivu Bendy na Beethovenovo dílo se Pečman kloní k názoru. že spíše než přímé souvislosti je nutné zdůraznit př́ibuzný skladatelský typ obou mistrů a jejich výše zmíněná filosoficko-estetická východiska. Při srovnání konkrétních uměleckých děl se nabízí důraz na expresivitu, předmětem zájmu se může stát též tematika dramatických děl, charakteristika jejich postav apod.

$\mathrm{Z}$ těchto pozic přistupuje Pečman $\mathrm{v}$ samostatné studii ke srovnání Bendova stěžejního jevištního díla, Vesnického trhu, s Beethovenovým Fideliem. ${ }^{16}$ Východiskem jsou mu myšlenky Vladimíra Helferta o latentní př́tomnosti tzv. beethovenovských prvků v Bendově díle. Helfert tvrdí ve studii Průkopnický význam české hudby v 18. stoleti (1939), že Benda předjímá Beethovenův hudební jazyk. Patrný je zejména vliv singspielu Der Dorfjahrmarkt (poprvé proveden 10. února 1775 v Gothě), jehož árie jsou svým dramatickým napětím předzvěstí některých árií z Fidelia. Helfert však tyto myšlenky dále nerozvádí, např. v samostatné studii. Pouze okrajově se na toto téma vyjadřuje v německém vydání Vesnického trhu (1930).

16 Benda's „The village market“ as a precursor of „Fidelio“: reflections on a marginal note by Vladimír Helfert. In Sborník prací Filozofické fakulty brněnské univerzity, H 5, 1970 , s. $141-150$. 
Pečman shledává v Bendovi progresivní zjev v oblasti hudebního divadla, který se spíše než na vystižení charakterů soustředil na vyjádření dramatické situace. Ta je dána jednak vývojem jevištního děje, jednak situační komikou - komickou prrirozeností situace. Tyto rysy směřují jak k Fideliovi, tak k rané romantické opeře, kterou anticipuje rovněž Fidelio. U obou hudebních dramatiků lze nalézt obdobné výrazové prostředky, zejména $\mathrm{v}$ důrazu na expresivitu.

Benda i Beethoven tak společně uznávají životnost singspielu. Tuto původně málo závažnou formu rozvíjejí nekonvenčním způsobem při hledání vážnějšího výrazu, dramatičnosti a vnitřního napětí. U Fidelia lze pak pozorovat pouze obrysy singspielu - forma singspielu slouží jako model, do něhož pronikají podněty hnutí Sturm und Drang, francouzské revoluční opery atd. Benda i Beethoven učinili ze singspielu vážný umělecký útvar, který stál u zrodu raně romantické německé opery.

Dále Pečman rozebírá blízkost dramatických charakterů obou děl. Zajímavá je např. komická postava tělnatého Fickfacka ve Vesnickém trhu. Jeho kořeny sahají k italské commedii dell'arte (Capitano), Benda z něj však vytváŕí dramatickou postavu, jež hudebně předjímá Dona Pizarra. Hudební souvislosti dokládá Pečman analýzou Fickfackovy a Pizarrovy árie: Was für Gesperre (č. 14) - Ha! welch ein Augenblick (1. dějství, č. 8).

Při formulaci paralel mezi Bendou a Beethovenem neopomene Pečman připomenout, že oba žili a tvořili v jiné době - Benda byl o 48 let starší. $Z$ tohoto hlediska se skutečně jeví jako Beethovenův předchůdce. Podobně přistupuje Pečman též k vztahu Beethovena a Bedřicha Smetany (viz dále).

\section{Okruh českého hudebního klasicismu}

Dílčí studie věnuje Pečman též dalším českým tvůrcům období klasicismu. Bez hlubší analýzy líčí pouhé okolnosti vzniku Beethovenovy drobné skladby Rasch tritt der Tod den Menschen an (Smrt na svou kořist nečeká, WoO 104). Marginální charakter studie podtrhuje i její název. ${ }^{17}$ Beethoven tuto kantátu pro 2 tenory a bas à cappella napsal pod dojmem náhlé smrti (2. května 1817) svého blízkého př́tele Václava Krumpholze. Krumpholz, bratr harfového virtuosa Jana Křtitele Krumpholze, byl vynikající houslista a virtuos na mandolínu. Patřil k prvním, kdo rozpoznali Beethovenovu velikost. Sám Beethoven k němu chodil do hodin houslové hry.

Tato kompozice, ač je inspirována Schillerovým Vilémem Tellem, nemá hlubší vztah k Beethovenovým jevištním skladbám. Jedná se o př́ležitostný smuteční vícehlas, který využívá krátkého textového úryvku z činohry.

17 Drobný př́spěvek k otázce vztahu Václava Krumpholze k Ludwigu van Beethovenovi. Bertramka, 1986, roč. 17 , č. 1-2, s. 1-5. 
Více pozornosti a úvah soustředí Pečman na dalšího z Čechů, kteří se ocitli v Beethovenově blízkosti. Je jím Václav Jan Stich-Punto, virtuos na lesní roh. ${ }^{18}$ Předmětem zájmu je tu především Beethovenova Sonáta $F$ dur, op. 17 pro klavir a lesní roh, která vznikla ze Stichova podnětu. Pečman se zabývá hudební strukturou díla a vlivem Sticha na jeho nástrojovou fakturu. Uvažuje, zda Beethoven mohl sonátu napsat během jednoho dne těsně před provedením (na hudební akademii ve Vídni 18. dubna 1800) a vyjadřuje názor, že interpretaci oba umělci obohatili improvizací. Při analýze zařazuje tuto skladbu mezi typ sonát pro klavír a melodický nástroj, v němž - oproti dř́ivější praxi - je u melodického nástroje uplatňován koncertantní princip (podobně jako v Sonátě A dur, op. 47 „Kreutzerově" pro klavír a housle z let 1802-1803).

Pečman rovněž uvažuje o Stichově vlivu na Beethovenův instrumentální styl. Beethoven měl totiž v oblibě ty virtuosy, od nichž mohl získat nové poznatky o orchestrální i sólistické instrumentaci. V okruhu dechových nástrojů hledal ve Vídni poučení ohledně flétny, klarinetu a lesního rohu. Znalosti hornové sazby načerpal u Sticha, který jej seznámil s taji hry na invenční lesní roh. Pečman též vytváŕí hypotézu o vlivu těchto poznatků na hornové party v 2. až 9 . symfonii (např. využívání „krytí“, zvuk nástroje v nízkých polohách), kterou však dále nerozvádí.

\section{Fidelio jako typologický předobraz Dalibora}

Z hlediska lineárního vývoje časového vrcholí česká beethoveniana Rudolfa Pečmana dílem Bedřicha Smetany. Tomuto tématu věnuje pozornost v osmdesátých letech. ${ }^{19}$ Konstatuje, že vliv Beethovena na Smetanu nebyl dosud soustavně zkoumán a odkazuje v této souvislosti na ojedinělé pasáže v dílech Vladimíra Helferta (Tvưrči rozvoj Bedřicha Smetany, 1924) a Zdeňka Nejedlého (Bedřich Smetana: doba zrání, 1962).

Pečman nejprve řeší otázku, kde a jak se Smetana seznámil s Beethovenovým dílem. V mládí navštěvoval nedělní koncerty dechové hudby na Barvířském (Žofinském) ostrově. Vojenskou hudbu 28. pěšího pluku hraběte Theodora Franze Baillet de Latour tam ř́́dil kapelník Emil Tittl. Během těchto koncertů zazněly také úpravy skladeb Mozartových, Mendelssohnových a Beethovenových. Po letech Smetana vzpomínal, že mu Tittlovy koncerty poskytly cenné umělecké podněty.

Hlavním zdrojem Smetanova zájmu o Beethovena však byla studia u Josefa Proksche. Proksch např. při výuce instrumentace kladl mezi vzory též Beethovena. Smetanovi se stal styl vídeňského skladatele uměleckým vzorem, ale nikoliv

18 Stich-Punto a Beethoven. In Sborník praci Filozofické fakulty Brněnské univerzity, H 31, 1996, s. 83-91.

19 Beethoven a Smetana. In Hudební řeč Bedřicha Smetany: konsonance a disonance z hlediska hudby 20. století. Praha: Svaz českých skladatelů a koncertních umělců, 1986, s. 49-85. 
jednostranným. U Beethovena se učil logice hudební architektury, důsledné práci s motivem; ve výrazu hudby se naopak inspiruje romantiky (Carl Maria von Weber) a novoromantiky (Hector Berlioz). Tato polarita je patrná již ve Smetanových raných kompozicích. Symfonie Es dur, ,,Triumfálni" je vystavěna na architektonickém plánu klasické symfonie (Beethoven, Schubert), avšak přináší některé osobité romantické inovace, např. ve $S$ cherzu. Rovněž v Triu g moll se nad beethovenovskou strukturou nese schumannovský typ melodiky a způsob jejího exponování.

Hlavní pozornost věnuje Pečman vztahu dvou jevištních děl, Fidelia a Dalibo$r a$. Hned v úvodu odmítá tradici tzv. reminiscencí z Fidelia, které formuluje Zdeněk Nejedlý patrně v návaznosti na Wilhelma Taperta, který se zabývá hledáním melodických podobností v dílech různých autorů (Wandernde Melodien, 1868). Pečman v odpovědi na tento názor konstatuje, že mezi Fideliem a Daliborem neexistují žádné melodické, rytmické nebo harmonické vztahy.

V rámci postižení možné analogie obou oper klade nejprve otázku, zda Smetana mohl znát Beethovenův singspiel ještě před kompozicí Dalibora. Ten byl totiž uveden již 16. května 1868, téměř dva roky před pražskou premiérou Fidelia (12. ledna 1870). Vzhledem k tomu, že Smetana Fidelia dlouhodobě prosazoval, je pravděpodobné, že byl s tímto dílem obeznámen dříve, než přistoupil ke kompozici své opery. Pečman dále stanovuje rozdíly ve formě a idejích. Zdůrazňuje pritom skutečnost, že kompozice vznikaly v různých dějinných a uměleckých epochách.

Zatímco Fidelio je typ vážného singspielu navazujícího na linii J. A. Bendy, Dalibor je hudební tragédie, vnitřně semknuté novoromantické dílo, které nemá $\mathrm{s}$ formou singspielu nic společného. Pečman poukazuje na názor Otakara Hostinského o „typickém českém“ vyznění díla, avšak bez vysvětlení, co se tímto pojmem rozumí. Rozdílný je rovněž závěr. Zjevení ministra Fernanda ve stylu barokizujícího principu deus ex machina vychází ze singspielové formy, která předpokládá radostné nebo útěšné vyznění (lieto fine). Naopak Dalibor je zakončen v duchu hudební tragédie 19. století. Rovněž pojetí lásky milujících žen je rozdílné. Fidelio je oslavou lásky manželské, Dalibor apoteóza lásky milenecké. Vztah Leonory k Florestanovi je stabilní, naopak u Milady lze pozorovat dramatický vývoj - přechod od nenávisti v obdiv a lásku. Pečman tu upozorňuje na prvek antického dramatu s poukazem na Gluckovu Armidu (1777).

Jaký je tedy užší vztah mezi oběma jevištními díly? Místo hledání melodických aj. podobností je nutno zaměřit se na typologii těchto oper. Pečman tvrdí, že Fidelio není blízký Daliborovi tzv. konvencionálními citacemi hudby, ale duchem. Předmětem analýzy má být postižení vnitřní duchovní souvislosti obou oper. Jinými slovy, z hlediska operní typologie nelze vysvětlit genezi Dalibora bez Fidelia (podobně jako Fidelia bez Bendova Vesnického trhu).

Obě díla představují typ tzv. osvobozovací opery. U Beethovena se jedná o obecně lidské pojetí svobody ve smyslu idejí Francouzské revoluce. Svár obecných idejí je však zároveň pozůstatkem staré metastasiovské opery. Dalibor, 
který vzniká v jiné epoše a v jiném duchovním prostředí, stanovuje konkrétní problém svobody na pozadí přímých dramatických dějů. Vnitřní spojitost lze nalézt zejména $\mathrm{v}$ žalářních scénách a $\mathrm{v}$ pojetí jevištních dvojic. $\mathrm{V}$ této souvislosti Pečman uvádí dvojice postav (Leonora - Milada, Rocco - Beneš, Florestan Dalibor, Pizzarro - Vladislav, Marcellina - Jitka, Jacquino - Vítek), podrobně je popisuje a formuluje společné i odlišné rysy.

Rozdíly nachází ve zhudebnění scén vojenských stráží a zbrojnošů. Ve Fideliovi mají stráže z hlediska dějového pouze statický charakter. Oproti tomu Smetanovi zbrojnoši mají dramaticky nosné a pohybově dynamické postavení. Ojedinělým prvkem, který se nachází pouze u Beethovena, je dramatická scéna sboru vězñù.

Lze tedy konstatovat, že Smetana měl při kompozici Dalibora tvůrčí a dynamický vztah k Fideliovi. Nepropadl v žádném př́ípadě epigonství: Beethovenův singspiel byl podnětem, který vedl k novému řešení.

Pečman v rámci okruhu úvah Beethoven - Smetana neopomíjí též dvě Smetanovy kadence k Beethovenovu Klavírnímu koncertu č. 3 c moll, op. 37. Smetana si tento koncert oblíbil a často jej hrával. Podnětem k vytvoření kadencí byla tedy jeho vlastní pianistická praxe.

Analýza kadencí je založena na konfrontaci s kadencemi Ference Liszta a Clary Schumannové. Odlišnost je zejména u první kadence, kde Smetana exponuje - na rozdíl od Liszta a Schumannové - vedlejší téma první věty. Proto je zdůrazněn lyrický prvek. Druhá kadence vychází tradičně z hlavního tématu téže věty a oproti první, jež je pojata homofonně, má př́sně kontrapunktický charakter.

\section{Závěr}

Pečmanova česká beethoveniana mají významné postavení v českém muzikologickém bádání o vídeňském skladateli. Nejhlouběji se tu Pečman věnuje estetickým a tektonickým vztahům mezi Beethovenovým Fideliem, Bendovým Vesnickým trhem a Smetanovým Daliborem. Toto zaměření odpovídá jednomu ze stěžejních témat jeho výzkumů, které soustředil na jevištní dílo Ludwiga van Beethovena. Odhalil tak logickou vývojovou linii tří tvưrců: Benda - Beethoven - Smetana, respektive jejich dramatických skladeb: Vesnický trh-Fidelio-Dalibor.

Pavel Sýkora (sykora@jamu.cz), Janáčkova akademie múzických umění, Brno. 


\section{ABSTRACT RUDOLF PEČMAN'S CZECH BEETHOVENIANA}

Beethoven's personality and work is the foremost element in the musicological heritage created by Rudolf Pečman that is manifested especially by his monograph Ludwig van Beethoven's Stage Work (1999). In the 1950s Pečman examined the slavonic subjects in Beethoven, mainly the relations between Russian folk songs and String quartets op. 59 - Rasumovsky. The world of Czech musical classicism is represented by Georg Anton Benda in particular. Pečman finds the elements common to both composers in their philosophical and aesthetic sources, e.g. the appassionata style. This view is applied to the dramatic relationship of two singspiels, The Village Market and Fidelio. Pečman also creates the similar analysis of two stage works, Fidelio and Smetana's Dalibor. He formulates common features and differences of these dramas, e.g. the inner spiritual connection and operatic typology.

\section{Key words}

stage work, Czech musical classicism, Slavonic origins, quotation of Slavonic songs, inner drama, J. A. Benda, appassionata style, theory of affects. philosophical and aesthetic sources, singspiel, expressivity, B. Smetana, Dalibor, musical tragedy, operatic typology, opera of deliverance

\section{Bibliography}

Ludwig van Beethoven im Herzen Europas. Leben und Nachleben in den Böhmischen Ländern. Oldřich Pulkert - Hans Werner Küthen - Karel Boženek (eds.). Prag: Resonus, 2000.

PEČMAN, Rudolf. Ästetisch-theoretische Ausgangspunkte und stilistische Verwandtschaft im Schaffen von Jiří Benda und Ludwig van Beethoven: Versuch um eine Komparation. In Sborník prací Filozofické fakulty Brněnské univerzity, H 2, 1967, s. 43-52.

PEČMAN, Rudolf. Beethoven a Smetana. In Hudební řeč Bedřicha Smetany: Konsonance a disonance $z$ hlediska hudby 20. století. Praha: Svaz českých skladatelů a koncertních umělců, 1986, s. 49-85.

PEČMAN, Rudolf. Beethoven pianista: slovo o jeho interpretačním umění a o správném vyznění jeho děl. Opus musicum, 1977, roč. 9, č. 2, s. 43-46.

PEČMAN, Rudolf. Beethovens Opernpläne. Brno: Univerzita J. E. Purkyně, 1981.

PEČMAN, Rudolf. Benda's „The village market“" as a precursor of „Fidelio“: reflections on a marginal note by Vladimír Helfert. In Sborník praci Filozofické fakulty brněnské univerzity, H 5, 1970, s. 141-150.

PEČMAN, Rudolf. Česká pocta Beethovenovi. Brno: Koncertní oddělení Parku kultury a oddechu, 1977.

PEČMAN, Rudolf. Drobný příspěvek k otázce vztahu Václava Krumpholze k Ludwigu van Beethovenovi. Bertramka, 1986, roč. 17, č. 1-2, s. 1-5.

PEČMAN, Rudolf. Dvě jihoslovanské písně v Beethovenově „Pastorální“. Hudební rozhledy, 1957 , roč. 10 , č. 11 , s. $455-457$.

PEČMAN, Rudolf. Jevištni dílo Ludwiga van Beethovena. Brno: Masarykova univerzita v Brně, 1999.

PEČMAN, Rudolf. Jiří Antonín Benda a Ludwig van Beethoven: pokus o srovnání jejich vzájemného slohového vztahu. Československá beethoveniána, 1965, roč. 2, č. 3, s. 142-154.

PEČMAN, Rudolf. K otázce slohového vztahu Jiř́ho Bendy a Ludwiga van Beethovena. Musejni zprávy Pražského kraje, 1959. roč. 4, č. 1-2, s. 24-34.

PEČMAN, Rudolf. Ludwig van Beethoven und Jiří Antonín Benda. In Bericht über den Internationalen Beethoven-Kongreß. Berlin: Verlag Neue Musik, 1971, s. 453-464. 
PEČMAN, Rudolf. „Minimalistische“ Kompositionen Ludwig van Beethovens: Zauber der vergessenen Albumblätter. In Od Perotina po Steva Reicha: idey ,,minimálneho “ v hudobných dejinách a v súčasnosti. Bratislava: Hudobné centrum, 2005, s. 130-146.

PEČMAN, Rudolf. Práčův písňový sborník z r. 1790 a „Razumovské kvartety“ L. van Beethovena: př́spěvek k otázce citací ruských lidových písní. In Sborník prací filosofické fakulty brněnské university, řada uměnovědná, 1957, č. 1, s. 53-63.

PEČMAN, Rudolf. Slawische Sujets in den Opernplänen L. van Beethovens. In Hudba slovanských národi̊ a její vliv na evropskou hudebni kulturu. Brno: Česká hudební společnost, 1981, s. $353-363$.

PEČMAN, Rudolf. Slovanské prvky v díle Ludvika van Beethovena. Brno: Filosofická fakulta Masarykovy university, 1954, rkp.

PEČMAN, Rudolf. Stich-Punto a Beethoven. In Sborník praci Filozofické fakulty Brněnské univerzity, H 31, 1996, s. 83-91.

PEČMAN, Rudolf. Tři česká beethoveniana. In Ludwig van Beethoven: miscellanea da camera. Rudolf Pečman (ed.). Brno: Koncertní oddělení PKO, 1987, s. 31-50.

PLEVKA, Bohumil. Beethoven a Praha. Praha: Supraphon 1975.

PLEVKA, Bohumil. Beethoven v českých lázních. Liberec: Severočeské nakladatelství, 1975.

RACEK, Jan. Beethoven a české země. Brno: Universita J. E. Purkyně, 1964.

RACEK, Jan. Beethoven: růst hrdiny bojovnika. Praha: SNKLHU, 1. vyd.1955, 2. vyd.1956.

ŠTĚDROŇ, Bohumír. Beethoven lidový: chorál dělnictva podle Beethovenovy sonáty. Časopis národního muzea. Oddíl věd společenských, 1963, roč. 132, s. 100-107.

ŠTĚDROŇ, Bohumír. Leoš Janáček a Ludwig van Beethoven. Universitas: revue Univerzity J. E. Purkyně v Brně, 1970, roč. 3, č. 4, s. 1-14.

ŠTĚDROŇ, Bohumír. Leoš Janáček und Ludwig van Beethoven. In Bericht über den internationalen Beethoven-Kongreß. Berlin: Verlag Neue Musik, 1971, s. 125-130.

ŠTĚDROŇ, Bohumír. Ludwig van Beethoven: člověk, umělec, revolucionář. Estetická výchova, 1965-66, roč. 4, č. 9, s. 370-373, č. 10, s. 422-424. 